\title{
A fé como porta da salvação
}

\author{
La foi porte du salut
}

Valeriano dos Santos Costa*

Resumo: A fé é um dom divino que, acolhido pelo homem, envolve todo o seu ser e promove a entrega incondicional e obediente àquele que é a fonte da salvação. Então a fé é a porta da salvação para quem reconhece que sem o Deus vivo, revelado por Jesus Cristo, não há como superar o peso da culpa, o império do mal, a ameaça da morte e até o medo da própria sobrevivência. Acolhido no coraç̃o da Santíssima Trindade, por meio do mistério pascal de Cristo, o crente recebe o dom do amor e da misericórdia para viver o espírito filial e torna-se uma nova criatura, cuja juventude se renova como a da águia. Esta reflexão é baseada no salmo 103, 3-5, em sua perspectiva cristológica.

Palavras-chave: Fé, Deus, Salvação, Culpa, Trindade.

Resumé: La foi est um don divin qui, accueilli par l'homme, engage tout son être et promeut l'offre inconditionelle et obéissant à celui qui est la source du salut. La foi est docla porte du salut pour celui qui reconnaît que sans le Dieu vivant, revelé par Jésus Christ, il n’y a pas comment surmonter le poids de la faute, l'empire du mal, le menace de la mort et jusque la peur de la propre survivance. Accueilli au coeur de la Sainte Trinité, atravers le mystère pascal du Christ, le croyent reçoit le don de l'amour et de la misericorde pour vivre l'esprit filial et devient une nouvelle créature, dont la jeunesse se renouvele comme celle de l'aigle. Cette réflexion est basée sur le psaume 103,3-5, dans sa perspective cristologique.

Mots-clés: Foi, Dieu, Salu, Responsabilite, Trinite.

* Doutor em Liturgia pelo Pontifício Ateneo Santo Anselmo, Roma. Diretor e Professor da Faculdade de Teologia Nossa Senhora da Assunção da PUC/SP. 
Quando o Papa Bento XVI proclamou o Ano da Fé, de 11 de outubro de 2012 a 24 de novembro de 2013, ${ }^{1}$ estimulou os teólogos a aprofundar o mistério da fé e a somar com toda a Igreja em sua busca por uma nova evangelização para a transmissão da fé cristã tema do último Sínodo dos Bispos presidido por Bento XVI, ocorrido em outubro de 2012, considerado grande ato do Sumo Pontífice antes da sua histórica renúncia. Apesar de o Papa não ter deixado um documento final com as propostas sinodais, o Sínodo, no entanto, nos deixou um instrumento de trabalho - instrumentum laboris ${ }^{2}$ - como base para as discussões que ocorreram na sala sinodal. O documento contém interessantes pistas sobre o que se pensa de uma evangelização capaz de restabelecer a transmissão da fé cristã numa cultura secularizada, na qual a família não é mais a primeira escola de evangelização nem o berço cultural da fé católica. Porém, antes de se pensar na nova evangelização para a transmissão da fé cristã, é preciso responder à pergunta: o que é a fé? É o que nos propomos neste ensaio teológico, começando pelo verbo crer, que é o movimento que sustenta $o$ ato de fé.

Embora Santo Tomás defina que "crer é um ato do intelecto, que assente à verdade divina, por império da vontade, movida pela graça de Deus", "a fé bíblica, vista como um todo, é um ato psíquico mais amplo do que o ato de fé definido por Santo Tomás de Aquino". ${ }^{4}$ É nessa perspectiva que podemos entender que "para a Bíblia, a fé é a fonte e o centro de toda a vida religiosa". ${ }^{5}$ Por isso mesmo, a fé, para FISICHELA, é "forma da existência pessoal". ${ }^{6}$ Se a fé tem um elemento racional intrínseco, ela se define muito mais pelo seu aspecto afetivo, que a vontade, enquanto potência da razão, sozinha não consegue abarcar. Talvez o termo "império da vontade”, posto por Santo Tomás,

1 CARTA Apostólica sob forma de “motu proprio" Porta Fidei. 3. impr. São Paulo: Paulinas, 2012.

SÍNODO DOS BISPOS XIII. ASSEMBLEIA ORDINÁRIA. A nova evangelização para a transmissão da fé. Instrumentum laboris. Vaticano: Libreria Editrice, 2012.

3 "Ipsum autem credere est actus intelectus assientientis veritatae divinae ex imperio voluntatis Deo, motae per gratiam": Suma teológica, II, II, Q 2a. 9.

4 McKENZIE, John L. Fé. In: Dicionário Bíblico. 8. ed. São Paulo; Paulus, 2003. p. 340.

5 DUPLACY, Jean. Fé. In: LÉON-DUFOUR, Xavier. Vocabulário de teologia bíblica. Petrópolis: Vozes, 2002. coluna 336

6 FISICHELLA, E. Fé. In: VV.AA. Dicionário teológico enciclopédico. São Paulo: Loyola, 2003. p. 292 queira significar a determinação do crente, que quando decide crer não há nada que o impeça. É nesta linha que podemos entender a afirmação de Jesus: se tiverdes fé como um grão de mostarda, direis a este monte: Transporta-te daqui para lá, e ele se transportará, e nada vos será impossível (Mt 17,20-21).

A fé, portanto, desde seus fundamentos no Antigo Testamento, os quais nos induzem à conexão elementar entre fé e confiança, como um binômio inseparável ${ }^{7}$ ou estrutura fundamental do ato de crer, ${ }^{8}$ tem seu conceito mais elaborado em São Paulo, que pode ser resumido numa frase curta, mas contundente: a fé é um ato de confiança pelo qual o homem se entrega a Deus, pela adesão a Jesus e ao querigma, como a única fonte da salvação. ${ }^{9}$ A adesão ao Filho de Deus, morto e ressuscitado, leva à proclamação querigmática do senhorio de Jesus Cristo. Isso constitui a confissão pública da fé cristã, que, ao apontar Deus como única fonte da salvação, reconhece que "a história da salvação, que possui o seu núcleo fundamental no mistério pascal de Cristo, é o lugar de onde brota o louvor" ${ }^{10}$ Codificado como esquema da fé, o credo é símbolo, isto é, expressão da fé, cuja confissão tem como matriz a contemplação das maravilhas de Deus na história e

7 Mueller pensa que uma boa possibilidade de se analisar a fé no Antigo Testamento é a raiz aman de alguns termos-chave, cujo significado é "ser firme, estável, confiável”. A fé envolve uma relação indissolúvel entre sujeito e objeto, com ênfase no caráter de confiabilidade no objeto da fé, que é Deus. Porém a fé, como expressão da relação de confiabilidade que Deus dá o homem, não se manifesta somente onde o termo fé aparece. Muitas histórias contadas ao longo do Antigo Testamento têm por objetivo discorrer sobre a confiabilidade que o Deus vivo merece e mostrar que os outros deuses e os ídolos ño passam de parque o Deus vivo merece e mostrar que os outros deuses e os ídolos não passam de parceiros nos quais o homem nunca deveria conflar. CF. MUELLER, Enio R. Fé. In: BOTELHO FILHO, Fernando (org.). Dicionário brasileiro de teologia. São Paulo: Aste, 2008. p. 442 Cf. DE SIMONE, R. J. Fé. In: DI BERARDINO, Angelo. Dicionário de antiguidades cristãs Petrópolis: Vozes, 2002. p. 566.

8 Referindo a Buber, Karrer concorda que houve uma clivagem entre o conceito helenístico e o conceito veterotestamentário da fé. A fé, no Antigo Testamento, tem como estrutura a confiança, enquanto que para o helenismo, a fé é pautada pela aceitação de algum bíblico-teológico. São Paulo: Loyola. 2000. p. 152

9 Cf. Bíblia de Jerusalém, nota de rodapé e, referente a Rm 1,16. 7. ed. São Paulo: Paulus, 2002. p. 1966

${ }^{10}$ DONGHI, A. Profissão de fé. In: SARTORE, Domenico; TRIACCA, Achille M. Dicionário de liturgia. São Paulo: Paulinas, 1992. p. 955. 
sua ressonância no espírito dos fiéis. ${ }^{11}$ Portanto, não se professa a fé como um código frio, mas como um ato de louvor e nisso consiste o querigma, considerando que kérygma, em grego, é o conteúdo de uma proclamação. Por isso é que se fala em adesão a Jesus Cristo e ao querigma. Isso sugere que a verdade sobre Jesus Cristo é, antes de tudo, proclamada como resposta de salvação, pois "a igreja foi chamada por Cristo para proclamar a mensagem da salvação a todos os homens, levando conta suas necessidades”. ${ }^{2}$ Proclamar a mensagem da salvação é anunciar Jesus Cristo e o querigma. Então a fé na ação de Deus em toda a história da salvação é a fé cristã, por ter no mistério pascal de Cristo seu núcleo fundamental. Podemos dizer que o conceito paulino de fé está plenamente fundado no Antigo Testamento e projetado para ser vivido na abertura confiante ao Mistério de Cristo, que caracteriza o Novo Testamento.

Então para o homem, ter fé é acreditar no Deus revelado por Jesus Cristo, como única possibilidade plenamente real e eficaz de salvá-lo de sua condição limitada e ansiosa, devido à necessidade intrínseca de liberdade e poder. É por isso que todo ser humano, por natureza, é ansioso. Se ele não souber conduzir a vida num processo de superação dos limites em vista da realização da liberdade, o nível de ansiedade aumenta a um patamar perigoso, transformando o desejo de liberdade e poder em agressão e doença. Em Gálatas, Paulo alude que a libertação promovida pela fé constrói uma vida pautada pela liberdade e não por novas escravidões: É para a liberdade que Cristo vos libertou. Permanecei firmes, portanto, e não vos deixeis prender de novo ao jugo da escravidão (Gl 5,1). Por isso é coerente pensar que todo ser humano é carente de salvação, e enquanto não chegar a este reconhecimento, pode-se dizer que ele está no nível primata no qual quer ser Deus (pecado original), mas vive como escravo. Nesse sentido o conceito de fé está intimamente vinculado ao conceito de salvação, enquanto este é o que motiva o homem a crer como quem quer apodera-se de um instrumento de libertação. Por isso é que a autossuficiência é inimiga da fé e constitui um bloqueio poderoso contra a possibilidade

\footnotetext{
1 Ibidem.

${ }^{12}$ Ibidem, p. 957
}

de crer. $O$ gesto litúrgico da prostração na sexta-feira santa, nas ordenações ministeriais e na bênção do abade, da abadessa, do rei ou da rainha mostra justamente a quebra de toda a autoconfiança, para se depositar a confiança somente em Deus, mediante a intercessão dos santos. É um gesto profundo de humilde, um pedido de ajuda àquele que pode nos salvar. ${ }^{13} \mathrm{O}$ ato de fé é, portanto, tem como sujeito aquele ser humano que se reconhece carente de salvação. Porém é necessário buscar o sentido mais profundo e abrangente do termo salvação para não cairmos em situações de indiferença religiosa como a que ocorre na Europa hoje, depois de ter chegado a progressos tais que parecem eliminar os limites diante dos quais a fé se apresentava como única solução.

O significado de salvação denota que a fé não é um ato desprovido de interesse, mas fundado no mais profundo e abrangente interesse humano: a libertação dos limites, dentre os quais a morte se destaca como a maior inimiga desta vida. Segundo uma nota da Bíblia de Jerusalém, a fé se baseia sobre a verdade e a fidelidade de Deus em cumprir suas promessas. ${ }^{14}$ A gênese bíblica da fé está no ato de confiança do Patriarca Abraão, que obedeceu ao chamado de Deus, e deixando tudo, seguiu com um grupo de pessoas pelo deserto, sem ponto de chegada predefinido e sem plano de volta. Sabia apenas que Deus o chamara e o mandara iniciar a grande viagem da fé. Aí se manifesta o aspecto coletivo da fé: nunca se caminha sozinho, de forma isolada.

Para Abraão, a promessa de uma posteridade que brotaria de si parecia cada vez mais distante, porque tanto ele como Sara, sua esposa, tinham idade avançada. Então como diz Paulo, era esperar contra toda a esperança (Rm 4,18). Mas Abraão creu e não deixou sua confiança ser abalada. Isso lhe foi levado em conta de justiça (Rm 4, 19). É a tese paulina da justificação pela fé. ${ }^{15}$ Portanto, Abraão foi jus-

${ }^{13}$ Cf. RÖWER, Basílio. Prostração. In: Dicionário litúrgico. Petrópolis: Vozes, 1947. p. 191. ${ }^{14}$ Cf. Bíblia de Jerusalém, nota de rodapé $e$, referente a Rm 1,16. 7. ed. São Paulo: Paulus, 2002. p. 1966.

${ }^{15}$ Justamente, o verbo crer desponta e adquire um caráter bíblico referencial em Genesis 15,6, quando Abraão creu em Deus e isso lhe foi tido em conta de justiça. Foi diante de um limite para o qual Abraão não tinha forças humanas de superar. Ele tinha saído da sua terra por um chamado de Deus, para formar um povo que nasceria de sua herança familiar. Porém, os anos estavam-se passando e tanto Abraão como Sara, sua esposa, já 
tificado não porque cumpriu preceitos legais, mas porque creu contra toda a esperança de cunho racional.

Por mais que a fé tenha um cunho coletivo, porque é vivida em comunidade, na comunhão e congregação dos que aceitam Jesus como Salvador, a dimensão individual é a que mais conta na hora de crer e assumir a autoentrega a Deus. São as promessas de Deus que instigam o homem a assumir o estatuto de crente, justamente porque essas promessas estão projetadas para o futuro, enquanto crer é um ato de confiança realizado no presente. Em que promessas o homem se baseia para fazer isso? O salmo expressa muito bem o que Deus realiza no crente que se entrega a ele por meio da fé:

\section{É ele quem perdoa todas as tuas faltas}

e cura todos os teus males.

É ele quem redime tua vida da cova

e te coroa de amor e compaixão.

É ele quem sacia teus anos de bens

e, como da águia, tua juventude se renova (Sl 103,3-5).

Nesta estrofe há cinco ações divinas que geram a perene juventude humana. Por isso movimentam o homem em direção da fé: 1) o perdão das faltas; 2) a cura de todo mal; 3) a redenção da morte; 4) o dom do amor e compaixão; 5) o provimento dos bens para a vida cotidiana. Por fim, o resultado é um movimento tão grande no ser da pessoa, que ela mesma renova sua juventude, comparada à juventude da águia.

A primeira ação de Deus é o perdão das faltas, fazendo a pessoa sentir-se em estado de justificação e não de culpabilidade. É o que Paulo chama de justificação pela fé. O homem não consegue manter-se de pé, se carrega o peso das culpas; é um fardo demais incômodo para

tinham idade avançada, com o agravante de que Sara, além de idosa, era estéril. Portanto havia uma barreira humanamente intransponível. Ao ver que Abraão estava enfrentando esse tipo de crise Deus the aparece e diz: $N a$ te (c) terei, se sequer um filho posso ter (Gn 15,2)? Então Deus conduziu Abraão para fora $e$ disse: ergue os olhos para o céu e conta as estrelas, se fores capaz, e acrescentou: assim será a tua posteridade (Gn 15,5). Abraão creu e isso foi tido em conta de justiça. Esse é o texto que Paulo cita para basear sua teologia na justificação pela fé e não pelas obras. suportar. É preciso que alguém tire esse peso dos seus ombros, do contrário ele mesmo tenta justificar-se colocando a culpa nos outros. Mas isso não funciona, chegando ao nível mais grave das doenças psíquicas, quando o psicopata mata e em plena consciência justifica-se afirmando que a vítima foi quem o provocou e até certo ponto obrigou-o a uma ação extrema. Esse desvio faz parte do pecado original, pois quando Adão foi questionado pelo motivo de sua desobediência, respondeu a Deus: A mulher que pusestes junto de mim me deu da árvore, e eu a comi $(\mathrm{Gn} 3,12)$. 0 agravamento do sentimento de culpa gera um complexo de culpa, que praticamente inutiliza a pessoa, pois ela fica presa a um emaranhado culposo que não a permite movimentar-se, como a abelha que cai na tenha da aranha. Quando o homem acredita que Deus o liberta das culpas, concedendo-lhe o perdão, começa a sentir-se como a ave que conseguiu fugir da armadilha do caçador. É um tremendo sentimento de liberdade e desenvoltura interior que se exprime em atos exteriores comparados a uma dança solta. Podemos então fazer a pergunta: como a culpa tornou-se um elemento tão opressor para a estrutura psíquica do homem, a ponto de se tornar, segundo o salmo, o objeto primeiro da salvação? É o que tentaremos abordar a seguir.

Como consequência do pecado, a ideia de culpa no Antigo Testamento (ashâm) não tinha nada de psicológico, mas definia um estado no qual o homem entra por causa do que aconteceu. ${ }^{16} \mathrm{~A}$ tentativa de se chegar ao estágio pessoal da culpa por meio do julgamento moral não anula a ideia de que a culpa é, antes de tudo, um estado mais abrangente no qual o homem é colocado, chegando-se à compreensão de que "quaisquer que sejam os níveis de responsabilidade pessoal, todos os homens vivem num clima geral de impotência moral. Ainda que não devamos a nossos ancestrais uma verdadeira culpa, eles nos legaram um tamanho fardo de falha moral que só podemos aspirar a uma intervenção divina que nos livre dele". ${ }^{17}$

${ }^{16}$ Cf. WILLIAMS, Rowan. Pecado. In: LACOSTE, Jean-Yves. Dicionário crítico de teologia São Paulo: Loyola, 2004. p. 1366

${ }^{17}$ Ibidem, p. 1367 
A segunda ação de Deus é consequência: a cura dos males. O mal é problema antigo e sempre novo, que aparece nos textos sagrados ou nos trágicos gregos, levantando perguntas, queixas, imagens de terror e cânticos de esperança. ${ }^{18}$ Sem dúvida, ocupa também boa parte das conversas do dia-a-dia. "Sentir" o mal é muito mais fácil do que compreendê-lo. De acordo com WESTELLE, as tradições filosóficas e teológicas se subdividem em grupos distintos, com seus argumentos fundamentais. O primeiro trata de atribuir o mal a um princípio ativo e ôntico (um ser), e o segundo nega que o mal tenha realidade ôntica como sua causa material e o trata como um recesso ao nada, um esvair-se ao não ser, uma condição incompleta. ${ }^{20}$ Seja como for, o mal é um parceiro indesejado que se torna objeto de salvação.

A salvação só pode ocorrer quando se toma consciência do mal e se consegue expressá-lo por meio de uma palavra autêntica. "Quando uma pessoa que se debate com o mal se expressa, suas palavras têm a marca da autenticidade, a sua linguagem nasce da experiência. Ela sofre e diz: 'isto dói'”. ${ }^{21}$ Em seu um grito de dor, aquele que sofre experimenta intensa reação emocional e abalos afetivos por causa da experiência de perigo, perdas fracasso, etc. ${ }^{22}$ Os males psíquicos e até físicos têm alguma raiz no complexo de culpa, pois a ansiedade da culpa promove a busca de compensações, dentre as quais o comer e o beber são os mais comuns. A má alimentação é responsável por muitas doenças. O desregramento das compensações afetivas completa o rol daquilo que vai envenenando o organismo e as estruturas psíquicas. A cura de todos os males implica em que todas as doenças comecem a

${ }^{18}$ Cf. JOSSUA, Jean-Pierre. Mal. In: EICHER, Peter (org.). Dicionário de conceitos fundamentais de teologia. São Paulo: Paulus, 1993. p. 518-519.

19 "Já as conversas do dia a dia referem-se ao escândalo dos sofrimentos físicos e morais, às condições sob que vivem os que sofrem diminuições de sua capacidade física e espiritual, à solidão aterradora. E ainda que os jovens sejam menos tocados por tal sofrimento pessoal, na verdade para eles o problema apenas se desloca: escandalizam-se com o racismo, com a fome no mundo, com a falta de disponibilidade para o diálogo entre os homens, com as ameaças à continuação da vida nesta nossa terra” (ibidem, p. 519)

${ }^{20}$ Cf. WESTELLE, Victor. Mal. In: BOTELHO FILHO, Fernando (org.). Dicionário brasileiro de teologia. São Paulo: Aste, 2008, p. 606.

de teologia. São Paulo: Aste, 2008, p. 606.
${ }^{21}$ JOSSUA, Jean-Pierre. Mal. In: EICHER, Peter (org.). Dicionário de conceitos fundamentais de teologia. São Paulo: Paulus, 1993. p. 519

${ }^{22}$ Cf. Ibidem. ser tratadas a partir da certeza trazida pela fé e da liberdade inerente que tira o crente do império da ansiedade e o coloca, pouco a pouco, na dimensão do equilíbrio.

Na esteira do mal está o terceiro efeito da salvação divina: a libertação da morte. 0 mal é tão temido, porque traz a ameaça da morte. Morte e medo se encontram numa cova que engole o ser humano e o encerra na escuridão das trevas. Como já foi dito, ser libertado da cova da morte é uma experiência semelhante à do pássaro que escapa da rede do caçador: Fugimos vivos como um pássaro da rede do caçador: a rede se rompeu e nós escapamos (Sl 124,7).

E como se processa a libertação da morte, se todos têm de passar por ela? Nem mesmo dos sofrimentos todos se curam. Temos de admitir que a fé é uma chave que pode abrir qualquer porta para quem consegue manejá-la. Nesse sentido, nem todos conseguem fazê-lo. Sobre isso diz JOSSUA:

E finalmente aquele sofrimento supremo que representa a morte - para uns possibilita um salto de sentido, liberdade criatividade, história, mas para outros total aniquilamento de sentido, pela qual os esforços humanos se tornam ridículos. ${ }^{23}$

Então passar pela morte é inevitável. O diferencial é, por incrível que pareça, a qualidade da morte. Paradoxalmente, se pode falar de uma morte ideal, já anunciada no Antigo Testamento. Sobre isso fala McKENZIE:

A morte ideal é aquela que sobrevém na plenitude da velhice, com as faculdades ainda intactas (Gn 25,8; Jó 21,23s; 29,18-20+). Quem morre nessas condições ideais, o faz de modo fácil e rápido: “desce em paz” ao Xeol (Jó, 21,13), não sendo vítima de morte prematura nem de uma longa doença destruidora, isto é, de uma morte com “alma amargurada" (Jó, 21,25). ${ }^{24}$

É no Novo Testamento que o mistério da morte chega à sua compreensão teológica mais alta, com a Páscoa de Cristo, o autor da vida.

${ }^{23}$ Ibidem.

${ }^{24}$ McKENZIE, John L. Morte. In: Dicionário Bíblico. 8. ed. São Paulo; Paulus, 2003. p. 633 
A morte de Cristo quebra os padrões da morte ideal apresentada pelo Antigo Testamento, sobretudo no que se refere à longevidade, porque se pode falar, no caso de Cristo, de uma morte prematura. No entanto uma coisa é clara como a luz do dia: na morte, Cristo preservou a integridade de suas faculdades e um equilíbrio exemplar que não se nota em uma alma amargurada. Ele morreu em plena consciência do significado de seu sacrifício e dos resultados para a salvação da humanidade, e reviveu para ser o Senhor dos vivos e dos mortos (Rm 14,9). Agora ele está ressuscitado e não morre mais, pois a morte não tem mais domínio sobre ele (Rm 6,9). A partir de então, a morte ideal é a morte com Cristo, fruto de uma vida em Cristo. Não importam mais a quantidade dos anos que marcam a extensão de uma vida, porque agora o tempo é kairós, isto é, graça. Somente a fé pode proporcionar essa nova visão da realidade histórica e possibilitar como entrar e sair dela com tranquilidade e paz. E o faz porque somente a fé pode criar o "homem novo", recriado no sangue de Cristo, isto é, na morte e ressurreição do Filho de Deus. O homem renovado em Cristo sabe que não pode evitar a morte e nem sequer impor a Deus que lhe conceda a longevidade. Então faz sentido perguntar: qual é o antídoto contra a morte que mata a própria morte, a ponto de Paulo zombar dela com provocações que denotam o fracasso e a prostração de quem se julgava ter antes um poder soberano, mas agora jaz no vale dos vencidos: Morte, onde está a tua vitória? Morte, onde está o teu aguilhão (1Cor 15,55)? Só podemos encontrar a resposta em um dom apontado pelo salmo como o quarto elemento da experiência da salvação proporcionada por Deus: o dom do amor e da misericórdia.

O amor, traduzido pelo Novo Testamento com a palavra grega agape, é a chave da fé que abre todas as portas, inclusive a porta da morte, derrotando-a e gerando um sabor místico de vitória, porque a morte perdeu o poder sobre Cristo e sobre seus seguidores. A vitória de Cristo sobre a morte, pela sua ressurreição gloriosa, significa também o nosso triunfo sobre a morte, expresso em aleluia pascal. Se a morte parecia absoluta, porque ninguém escapava do seu domínio ou fugia ao seu aguilhão, agora ela está humilhada e confusa, porque é encarada e não mais temida como antes. Realmente, a morte, para Paulo, se tornou objeto de gozação.
Estudos sobre a palavra agape, ${ }^{25}$ no contexto do Novo Testamento, são preciosos instrumentos para compreendermos a extensão do amor de Deus em nossa vida de fé. A Escritura como um todo, o Evangelho de Cristo, a missão da Igreja, os sacramentos e as pastorais só podem ser corretamente compreendidos sob o prisma do amor de Deus, que para Agostinho tem consistência substancial e, por isso, não é uma abstração. Diz Agostinho: "Se o amor fosse nada, como se diz que Deus é amor (1Jo 4,16)? E se não e uma substância, como se diz que Deus é substância?”. ${ }^{26} \mathrm{O}$ grande perigo para a fé é fazermos do amor de Deus uma abstração sem incidência afetiva, de tal modo que outros afetos sejam os referenciais para as decisões mais importantes da vida. Na hora de se escolher o futuro, a companhia afetiva, enfrentar dilemas, é o amor de Deus que faz o diferencial? 0 indiferentismo religioso mostra que Deus não conta mais nesses momentos vitais; por isso sua existência é indiferente para a vida real. Uma fé fundada em obrigações para com "esse Ser estranho" não tem solidez e leva rapidamente ao desvencilhar-se dele. São os afetos que nos movem. Quando o amor de Deus é um referencial abstrato e não desce ao nível dos afetos, a fé está terrivelmente comprometida, porque segundo Paulo, a fé só é autêntica quando age pelo amor, entendido como agape (cf. Gl 5,6). É que a natureza de agape é intrinsecamente oblativa, porque é cem por cento direcionada para o outro, como é a relação entre o Pai e o Filho, ${ }^{27}$ no coração da Santíssima Trindade. É dessa relação que nasce o projeto de salvação para o ser humano, criado à imagem e como semelhança (Gn 1,16), para ser, no tempo pleno da salvação, filialmente adotado pela graça.

${ }_{25}^{25}$ COSTA, Valeriano Santos. O amor de Deus: teologia da redenção. São Paulo: Palavra e Prece, 2012. p. 21-32; ZUBIRI, Xavier. El ser sobrenatural: Dios y la deificación en la teología paulina. Barcelona: Herder, 2008.

${ }^{26}$ AGOSTINHO. A Trindade. Livro 6,5. São Paulo: Paulus, 1995. p. 224

${ }^{27}$ "Então há um tipo de amor liberto de tal forma do foco egoístico, que é totalmente centrado no bem do outro. Esse amor, os cristãos o elevaram ao nível teológico. Por não ter seu foco no interesse sexual nem fazer o jogo das segundas intencões, foi visto como ter seu for nu in autêntico. Por isso usaram jogbém a pala um amor puro e autêntico. Por isso usaram também a palavra agape para falar de Deus definir a relação entre as Pessoas divinas, bem como para expressar o que Deus sente por nós e o que devemos sentir uns pelos outros" (COSTA, Valeriano Santo. O amor de Deus teologia da redenção. São Paulo: Palavra e Prece, 2012. p. 25). 
Quando o salmo diz que Deus vai conceder o amor e a misericórdia, está anunciando o que Cristo vai realizar no tempo da graça, por meio da encarnação. E a graça foi-nos dada: o homem é filho adotivo, ou seja, filho no Filho. Foi preciso tanto tempo para se compreender que o ser humano é de natureza filial, e não paternal ou maternal em princípio. É demais exigir de alguém que carrega neuroses porque não se sentiu amado o suficiente por seus pais, por causa de um contexto familiar ruim, que seja bom pai e boa mãe. A condição filial, com tudo o que ela significa para a estrutura psíquica, é base para sanidade mental e para o equilíbrio da pessoa. Quando Deus passeava no jardim à brisa do dia, indo ao encontro de Adão e Eva, que já se tinham escondido por causa do pecado (Gn 3,8), alimentava neles a relação filial. Foi necessário, a partir daí, o tempo da espera para que a promessa de uma filiação muito superior, que Paulo chama de filiação adotiva por meio do próprio Filho, como Mediador, fosse gratuitamente realizada e ofertada a toda a humanidade, promovendo uma transformação radical na pessoa. A liturgia da Igreja não se cansa de celebrar essa transformação radical no ser e na existência da pessoa. Nisso está a índole da salvação, à qual o Missal Romano se refere constantemente, sobretudo no Tempo Pascal, quando a natureza no hemisfério norte se desabrocha em flor, como que celebrando a ressurreição após um inverno cinzento e triste. A tradição litúrgica consegue ver a transformação da natureza como sinal da transformação que a filiação adotiva concede ao ser humano. 0 tema da filiação é quase um refrão na Vigília Pascal:

Ó Deus pai de todos os fiéis,

vós multiplicastes por toda a terra os filhos da vossa promessa,

derramando sobre eles a graça da filiação

e, pelo mistério pascal, tornais vosso servo Abraão pai de todos os

povos, como lhe tínheis prometido.

Concedei, portanto, a todos os povos

a graça de corresponder ao vosso chamado. ${ }^{28}$

${ }^{28}$ Missal Romano, Domingo da Páscoa da Ressurreição do Senhor, Vigília Pascal, Oração depois da segunda leitura.
Então a graça da filiação adotiva corresponde à realização da promessa. É uma graça que vem do alto - é derramada - e não vem, portanto, da condição humana por si mesma. A oração depois da quarta leitura faz referência parecida: "Multiplicai a posteridade que prometestes aos nossos pais, aumentando o número dos vossos filhos adotivos". ${ }^{29}$ E mais incisiva ainda é a oração depois do hino do Glória, a qual encerra o período do Antigo Testamento:

Ó Deus, que iluminais esta noite santa

com a glória da ressurreição do Senhor,

despertai na vossa Igreja o espírito filial

para que, inteiramente renovados,

vos sirvamos de todo o coração. ${ }^{30}$

O projeto pascal de Cristo tem como objetivo geral: despertar na Igreja o espírito filial; e como objetivo específico: o serviço a Deus de todo o coração. Aqui percebemos o quanto o amor de Deus é a condição da nossa renovação em criaturas modeladas pela Páscoa de Cristo. Não se trata de condição moral, como se a vontade humana fosse o parâmetro das decisões pessoais. Trata-se antes de uma transformação ontológica, que incide diretamente na situação existencial. Não é à toa que a Vigília pascal é, por excelência, a noite batismal na tradição antiga da Igreja, pois é pelo batismo que nos tornamos filhos adotivos de Deus. Filho aqui significa filho amado como Jesus é amado. Para Paulo, o Filho é o Amado. ${ }^{31} \mathrm{Na}$ condição de filhos adotivos, somos também amados. Isso muda nossa estrutura psicoafetiva e provoca uma revolução em nossa existência. Neste segundo estágio, a vontade humana conta, mas ela é amparada por uma mudança radical em nosso ser, gratuitamente realizada por Deus. Se a fé não nos puder

${ }^{29}$ Ibidem. Domingo da Páscoa da Ressurreição do Senhor, Vigília Pascal, Oração depois da quarta leitura.

${ }^{30}$ Ibidem. Domingo da Páscoa da Ressurreição do Senhor, Vigília Pascal, Oração do Dia. ${ }_{31}$ Bendito seja Deus e Pai de nosso Senhor Jesus Cristo, que nos abencoou com toda a sorte de bênçãos espirituais, nos céus, em Cristo. Nele nos escolheu antes da fundação do mundo, para sermos santos e irrepreensíveis diante dele no amor. Ele nos predestinou para sermos seus filhos adotivos por Jesus Cristo, confirme decisão da sua vontade, para louvor e glória da sua graça, com a qual ele nos agraciou no Amado (Ef 1,3-6). 
dar algo que nos possibilite sair da escravidão do pecado, o que Paulo considera uma sujeição à lei natural, para que então serve acreditar em quem tem o poder de nos tirar da cova da morte, como o passarinho que escapa da rede do caçador? Foi a apresentação fácil e empolgante dessa boa notícia em forma de querigma que tornou o Apóstolo tão acolhido entre os gregos, pois só faltava uma proposta dessas, para o pensador grego vislumbrar a saída da escravidão que pode configurar a vida inteira. Era uma graça tão generosamente ofertada! Era aceitar ou largar! Muitos gregos a aceitaram prontamente, o que provocou certo mal estar em Jerusalém, porque as fronteiras judaicas já tinham sido definitivamente extrapoladas.

ZUBIRI tem um comentário sobre a obra paulina digno de consideração:

A obra paulina é, em primeiro lugar, uma catequese vivente destinada à constituição de comunidades cristãs agrupadas em torno de Cristo, que, gloriosamente, vive não só nos céus, mas também na terra, depois da ressurreição. Para São Paulo, o fundamento dessas agrupacões, dessas “igrejas” no seio da “Igreja”, não consiste tão somente na participação em certos ritos ou em certo regime de vida prática (ambas as coisas são somente consequência do dado fundamental), senão, sobretudo, em uma transformação da nossa existência, consequência, por sua vez de uma transformação do nosso ser inteiro, de uma deificação por sua união com Cristo. ${ }^{32}$

O que é magnífico nas palavras de ZUBIRI é a inversão de causa e efeito. Desatenciosamente, se considera, muitas vezes, que a revolução existencial da vida cristã causa a renovação interior da pessoa na fé. Nessa lógica o cristianismo é antes de tudo, o anúncio dos dogmas da fé e dos princípios morais que incidem na prática cristã. Mas aí há uma inversão de princípios, a qual é responsável pelos problemas que a evangelização feita sob esse molde não conseguiu superar. Por isso, o Instrumentum Laboris do Sínodo dos Bispos, mencionado no início deste artigo, previne a Igreja para não cair nessa armadilha:

${ }^{32}$ ZUBIRI, Xavier. El sobrenatural: Dios y la deificación en la teología paulina. Barcelona: Herder, 2008. p. 145. Obs.: A tradução é livre.
A fé cristã é não somente uma doutrina, uma sabedoria, um conjunto de regras morais, uma tradição. A fé cristã é um encontro real, uma relação com Jesus Cristo. Transmitir a fé significa criar em cada lugar e em cada tempo, as condições para que este encontro entre os homens e Jesus aconteça. O objetivo de toda evangelização é a realização deste encontro, que é ao mesmo tempo íntimo e pessoal, público e comunitário. ${ }^{33}$

A revolução existencial não é causa, mas efeito da renovação ontológica. Portanto a missão paulina não era levar novos costumes e regras, como muitas vezes entendemos a missão, mais levar o amor de Deus, para que a condição ontológica das pessoas se modificasse a tal ponto que, como diz a oração da Vigília Pascal, pudessem servir a Deus de todo o coração. Isso significava abandonar os velhos ídolos ineficazes e se entregar ao Deus vivo, anunciado no querigma. As pessoas não amam porque não querem, mas porque não conseguem. Daí é que a experiência da salvação é necessária para modificar a condição ontológica do homem, a fim que este consiga amar. O dilema paulino de querer uma coisa e fazer outra ${ }^{34}$ representa a luta interior de todo aquele que quer amar e não consegue. Somente a ajuda divina pode resolver o dilema, sem contudo ferir a liberdade de pecar, ou seja, de optar pontualmente por não amar ou de simplesmente não fazê-lo por inconsciência, por não deixar que a graça vá fundo das estruturas psíquicas para desbloquear os entraves ao amor, considerando que isso é um processo lento, uma ascese mística. O problema do senso comum é nivelar as ações mais profundas da vida no patamar ético-moral, onde as pessoas não amam porque são más, como se agissem por determinação acintosa da vontade.

${ }^{33}$ SÍNODO DOS BISPOS. XIII ASSEMBLEIA ORDINÁRIA. A nova evangelização para a transmissão da fé. Instrumentum laboris. Vaticano: Libreria Editrice. 2012. p. 9.

${ }^{34}$ Realmente não consigo entender o que faço; pois não pratico o bem que quero, mas faço o que detesto. Ora, se faço o que não quero, eu reconheço que a Lei é boa. Na realidade, não sou mais eu que pratico a ação, mas o pecado que habita em mim. Eu sei que o bem não mora em mim, isto é, na minha carne. Pois o querer o bem está ao meu alcance, não não mora em mim, isto é, na minha carne. Pois o querer o bem está ao meu alcance, não
porém o praticá-lo. Com efeito, não faço o bem que quero, mas pratico o mal que não quero. Ora, se faço o que não quero, já não sou eu que estou agindo e sim o pecado que habita em $\operatorname{mim}(\mathrm{Rm} 7,14-20)$ 
Não é só na Vigília Pascal ou no período litúrgico da Páscoa que a Igreja se preocupa com a condição filial dos batizados, mas também tem toda eucaristia dominical, pois aí se alimenta e se conserva a condição filial:

\section{Deus eterno e todo-poderoso,}

a quem ousamos chamar de Pai,

dai-nos cada vez mais um coração de filhos

para alcançarmos um dia a herança prometida. ${ }^{35}$

É nesse sentido que podemos compreender a exortação de Jesus: A ninguém na terra chameis de Pai, pois um só é vosso Pai, o celeste $(M t 23,9)$. $O$ fato de desempenhar a tarefa de pai e mãe nesta terra não muda a essência filial da natureza humana e leva a considerar que ser pai e mãe é graça de Deus, sustentada por uma graça anterior: a graça da filiação adotiva. É mediante tal graça que podemos, como Jesus, chamar a Deus Pai de $A b b a$, tradução grega do aramaico $A b a$. É um vocativo de origem aramaica, pronunciado por Jesus (Mc 14,36) e usado pelos primeiros cristãos (Rm 8,15; Gl 4,6), com a tradução ao lado, para indicar que nossa relação com o Pai deve chegar à intimidade com que as crianças tratavam carinhosamente seu pai, como se comprova em cartas aramaicas. ${ }^{36}$ Mas esse é um passo fenomenal da fé, ou seja, o passo decisivo em nossa relação com Deus. As três citações bíblicas elencadas acima do termo $A b b a$, com a tradução do lado, não foram sem acaso. Paulo é o grande teórico do que isso significa em termos de salvação. Ele justifica aos Gálatas que a nossa filiação divina é adotiva, puro dom do agape de Deus Pai. A fazer-nos filhos adotivos, Deus Pai enviou aos nossos corações o Espírito do seu Filho que clama $A b b a$, Pai! $(G l 4,6)$. Isso é o cheque-mate à nossa condição de escravos, pois nos tornamos herdeiros pela graça (cf. Gl 4,7). A herança de Deus é em primeira mão seu próprio ser, isto é o amor. A grande diferença é a forma como conseguimos: Cristo a tem por si mesmo e nós a temos por graça; pela participação seu Mistério Pascal. Mas a salvação realizada por de Deus é absurdamente justa com o pecador,

${ }^{35}$ MISSAL Romano, 19o Domingo do Tempo Comum, Oração do Dia.

${ }^{36}$ Cf. McKENZIE, John L. Morte. In: Dicionário bíblico. 8. ed. São Paulo: Paulus, 2003. p. 1. que passa por um processo de justificação sem mérito algum de sua parte; simplesmente Deus o adota e o ama. Então o pecador justificado sente-se amado como nunca por Deus, que sempre o amou, mas ele não foi capaz de perceber. E há uma consequência lógica do amor de Deus: agora ele sente desejo e é dotado de uma capacidade inerente de amar os outros. Então ele é cumulado de amor e compaixão, dons de Deus, que é amor em essência (1Jo 4,8). A fé transforma o ser humano em nova criatura ${ }^{37}$ que vive no amor (1Jo 4,9). Em outras palavras, a nova criatura é envolvida pelo amor como o ar que respira. Não se trata de uma virtude humana, mas antes de um dom sobrenatural.

A quinta e última ação de Deus é muito prática: o reflexo econômico. É natural que quem confia em Deus leve um tipo de vida produtiva em todos os sentidos, inclusive no sentido econômico. O salmo coloca em último lugar o que para o senso comum de pessoas ansiosas está em primeiro lugar: o que comer e o que beber para a sobrevivência cotidiana. Aqui se incluem todas as necessidades que constituem o direito básico a ser garantido por lei. Mas, para não viver sob o império da lei e não ser premido por ansiedade, o homem se entrega a Deus e sente-se livre para a missão, sabendo que a garantia da sobrevivência econômica está incluída no dom da fé:

Por isso vos digo: não vos preocupeis com a vida quanto ao que haveis de comer, nem com o vosso corpo quanto ao que haveis de vestir. Não é a vida mais do que o alimento e o corpo mais do que a roupa? Olhai as aves do céu: não semeiam, não colhem, nem ajuntam em celeiros. No entanto vosso Pai celeste as alimenta. Ora não valeis mais do que elas? (Mt 5,25-26).

Com todas essas garantias, o ser humano tem condições de se rejuvenescer contra o tempo, que envelhece naturalmente. Mas a fé é um dom sobrenatural. Embora não possa evitar as rugas e os desgastes da idade, o homem tem uma área interior plenamente sob seu controle a ser preservada. Fazendo isso, ele se mantém jovem como a águia, metáfora bíblica que nunca perdeu seu impacto. A fé faz alçar

${ }^{37}$ Se alguém está em Cristo, é uma nova criatura; passaram-se as coisas antigas; eis que se fez realidade nova (2Cor 5,17$)$ 
o projeto de vida humana como o sobrepujante voo da águia. Estar acima das agruras da terra e, a partir desse patamar, contemplar montanhas e vales é viver com liberdade de amar. Dessa forma, a fé é uma porta que abre o vasto horizonte da salvação para o ser humano. Como diz o Papa Bento XVI, "a porta da fé (cf. At 24,27), que introduz na vida de comunhão com Deus e permite a entrada na Igreja, está sempre aberta a nós" ${ }^{38}$ Está aberta porque o plano da salvação chegou a seu ápice histórico; agora declina na espera da adesão de todos que queiram passar pela porta da fé. Se a salvação está para além dessa porta, não podemos titubear em não encontrar o mais rápido possível a nova evangelização para a transmissão da fé, sob o risco de sermos julgados por omissão e medo. A proclamação do Ano da Fé deve ecoar em toda a Igreja e fazer-se sentir em cada badalo de sino que ainda soa neste mundo moderno. No peneirar do secularismo atual, a fé deve resistir até o fim, como resistiu no Apóstolo Pedro: Simão, Simão, eis que Satanás pediu insistentemente para vos peneirar como trigo; eu, porém, orei por ti, a fim de que tua fé não desfaleça (Lc 22-31-32).

\section{Bibliografia}

AGOSTINHO. A Trindade. Livro 6,5. São Paulo: Paulus, 1995.

BENTO XVI. Carta apostólica sob forma de "motu proprio" Porta Fidei. 3. impr. São Paulo: Paulinas, 2012.

COSTA, Valeriano Santos. O amor de Deus: teologia da redenção. São Paulo: Palavra e Prece, 2012.

JOSSUA, Jean-Pierre. Mal. In: EICHER, Peter (org.). Dicionário de conceitos fundamentais de teologia. São Paulo: Paulus, 1993. p. 518-524.

DE SIMONE, R. J. Fé. In: DI BERARDINO, Angelo. Dicionário de antiguidades cristãs. Petrópolis: Vozes, 2002. p. 565-569.

DONGHI, A. Profissão de fé. In: SARTORE, Domenico; TRIACCA, Achille M. Dicionário de liturgia. São Paulo: Paulinas, 1992. p. 953-961.

DUPLACY, Jean. Fé. In: LÉON-DUFOUR, Xavier. Vocabulário de teologia bíblica. Petrópolis: Vozes, 2002. colunas 336-345.

38 BENTO XVI. Carta Apostólica sob forma de "motu proprio" Porta Fidei. 3. impr. São Paulo: Paulinas, 2012. p. 3.
FISICHELlA, E. Fé. In: VV.AA. Dicionário teológico enciclopédico. São Paulo: Loyola, 2003. p. 292.

KARRER, M. Fé. In: BAUER, Joahnnes, B. Dicionário bíblico-teológico. São Paulo: Loyola, 2000. p. 152-156.

McKENZIE, John L. Fé. In: Dicionário Bíblico. 8. ed. São Paulo: Paulus, 2003. p. 340-343.

MUELLER, Enio R. Fé. In: BOTELHO FILHO, Fernando (org.). Dicionário brasileiro de teologia. São Paulo: Aste, 2008. p. 442-445.

RÖWER, Basílio. Prostração. In: Dicionário litúrgico. Petrópolis: Vozes, 1947. p. 191-192.

SÍNODO DOS BISPOS. XIII ASSEMBLEIA ORDINÁRIA. A nova evangelização para a transmissão da fé. Instrumentum laboris. Vaticano: Libreria Editrice, 2012

WESTELLE, Victor. Mal. In: BOTELHO FILHO, Fernando (org.). Dicionário brasileiro de teologia. São Paulo: Aste, 2008. p. 606-608.

WILLIAMS, Rowan. Pecado. In: LACOSTE, Jean-Yves. Dicionário crítico de teologia. São Paulo: Loyola, 2004. p. 1366-1370.

ZUBIRI, Xavier. El sobrenatural: Dios y la deificación en la teología paulina. Barcelona: Herder, 2008. 